\title{
PENGENALAN PROGRAM KEWIRAUSAHAAN BERBASIS INDUSTRI KREATIF BAGI SISWA SMP AL-JANNAH, PONDOK RANGON, JAKARTA TIMUR
}

\author{
Mei Ie ${ }^{1}$ dan Hetty Karunia Tunjugsari ${ }^{2}$ \\ ${ }^{1}$ Jurusan Manajemen, Universitas Tarumanagara Jakarta \\ Surel:meii@fe.untar.ac.id \\ ${ }^{2}$ Jurusan Manajemen, Universitas Tarumanagara Jakarta \\ Surel: hetty@fe.untar.ac.id
}

\begin{abstract}
In the midst of the government's active development of entrepreneurship programs and to encourage the emergence of new entrepreneurs, especially young entrepreneurs, the Head of SMP Al-Jannah sees the need for an active role from teachers and students from this school in supporting entrepreneurship programs nationally. The solution to the problems faced by partners is through the provision of seminars and workshops based on creative industries in the Virtual Foodtech event organized by the school, by inviting the Untar PKM team as a resource. Creative industry can be done through culinary product development. Culinary products are chosen to be developed because they are considered easier and culinary is also a necessity of many people. The purpose of this activity is to provide knowledge about the manufacture of creative industry-based products and raise awareness of students to carry out entrepreneurial activities. At the seminar, students will be provided with knowledge about entrepreneurial concepts, develop business ideas and also carry out business simulations. In the workshop activities, students will be equipped with skills to make products that are tailored to the interests and abilities of students to make them. The target of this PKM activity is to transfer knowledge about entrepreneurial values to Al-Jannah Middle School students. The method of implementing activities is to conduct in-depth interviews, study relevant literature, plan seminars and workshops, implement PKM activities that coincide with the implementation of Virtual Foodtech events, evaluate activities, and compile and submit activity reports. In general, these community service activities have been going well and the students have also given positive responses and hope that these activities can be carried out continuously.
\end{abstract}

Keywords: entrepreneurship, creative industry, virtual foodtech

\begin{abstract}
ABSTRAK
Di tengah giatnya pemerintah mengembangkan program kewirausahaan dan untuk mendorong munculnya wirausahawirausaha baru, terutama wirausaha muda, maka Kepala SMP Al-Jannah memandang perlunya peran aktif dari para guru dan siswa dari sekolah ini dalam mendukung program kewirausahaan secara nasional. Solusi permasalahan yang dihadapi mitra adalah melalui pengadaan kegiatan seminar dan workshop berbasis industri kreatif dalam acara Virtual Foodtech yang diselenggarakan oleh pihak sekolah, dengan mengundang tim PKM Untar sebagai narasumber. Industri kreatif dapat dilakukan melalui pengembangan produk kuliner. Produk kuliner dipilih untuk dikembangkan karena dianggap lebih mudah dan juga kuliner merupakan kebutuhan orang banyak. Tujuan kegiatan ini adalah untuk memberikan pengetahuan mengenai pembuatan produk berbasis industri kreatif dan meningkatkan kesadaran siswa untuk melaksanakan kegiatan kewirausahaan. Pada kegiatan seminar, para siswa akan dibekali pengetahuan mengenai konsep kewirausahaan, pengembangan ide bisnis dan juga melakukan simulasi bisnis. Pada kegiatan workshop, para siswa akan dibekali dengan keterampilan untuk membuat produk yang disesuaikan dengan minat dan kemampuan para siswa untuk membuatnya. Target kegiatan PKM ini adalah berupa transfer pengetahuan mengenai nilai-nilai kewirausahaan kepada para siswa/i SMP Al-Jannah. Metode pelaksanaan kegiatan adalah melakukan in deep interview, studi literatur yang relevan, menyusun rencana kegiatan seminar dan workshop, pelaksanaan kegiatan PKM yang bertepatan dengan pelaksanaan acara Virtual Foodtech, evaluasi kegiatan, serta penyusunan dan penyerahan laporan kegiatan. Secara umum, kegiatan pengabdian kepada masyarakat tersebut telah berjalan dengan baik dan para siswa/i juga memberikan tanggapan yang positif dan berharap kegiatan ini dapat dilaksanakan secara berkesinambungan.
\end{abstract}

Kata Kunci: kewirausahaan, industri kreatif, virtual foodtech

\section{PENDAHULUAN}

\section{Analisis Situasi}

Pencanangan Gerakan Kewirausahaan Nasional sejak tahun 2011 lalu oleh Pemerintah Indonesia telah mendorong munculnya kegiatan pengembangan kewirausahaan di berbagai bidang, baik oleh pemerintah, masyarakat, maupun swasta. Salah satu tujuan pendidikan dan penyelenggaraan 
kegiatan-kegiatan kewirausahaan tersebut adalah untuk meningkatkan jumlah wirausaha di Indonesia demi terwujudnya perekonomian Indonesia yang handal di masa mendatang. Melalui kegiatan kewirausahaan tersebut diharapkan dapat menciptakan calon wirausaha baru. Karakteristik psikologis, seperti pengambilan keputusan dan keyakinan diri, juga dapat dikembangkan melalui kegiatan tersebut. Dengan demikian diharapkan keinginan menjadi wirausaha dapat lebih meningkat.

Di berbagai negara dalam beberapa tahun terakhir ini, pemahaman mengenai pentingnya diadakan pendidikan kewirausahaan dalam rangka mendorong pertumbuhan ekonomi dan penciptaan lapangan kerja, terus meningkat. Pendidikan kewirausahaan tersebut dapat diimplementasikan melalui penyelenggaraan kursus maupun program kewirausahaan di dalam materi pelajaran yang diberikan di sekolah (Lynch et al., 2021).

Selain itu, pengembangan karakteristik wirausaha di berbagai lapisan masyarakat dan berbagai tingkatan pendidikan diharapkan mampu mencetak pribadi- pribadi unggul dengan karakter khas wirausaha, yaitu kreatif dan inovatif, memiliki rasa percaya diri yang tinggi, berani mengambil risiko, serta selalu berorientasi pada hasil (Jayalakshmi \& Saranya, 2015). Adanya gerakangerakan dan program kewirausahaan yang terus diadakan, maka beberapa tahun belakangan ini, jumlah wirausaha di Indonesia sudah menunjukkan adanya peningkatan, terutama untuk wirausaha muda. Sudah banyak anak muda yang tergerak dan termotivasi untuk menjadi wirausaha dengan menciptakan suatu produk atau usaha yang kreatif dan inovatif.

Kewirausahaan merupakan kemampuan kreatif dan inovatif yang menjadi dasar, kiat, dan sumber daya untuk mencari peluang dalam mencapai kesuksesan (Hasanah, 2015). Kegiatan kewirausahaan memiliki kaitan yang sangat erat dengan kreativitas. Kreativitas merupakan suatu proses mental yang dilakukan individu berupa gagasan ataupun produk baru atau mengkombinasikan antara keduanya yang pada akhirnya akan melekat pada dirinya (Rachmawati, 2005, dalam Destiani et al., 2016).

Kewirausahaan adalah semangat, perilaku, dan kemampuan untuk memberikan tanggapan yang positif terhadap peluang memperoleh keuntungan, baik untuk diri sendiri maupun orang lain (Hasanah, 2015). Kewirausahaan juga menciptakan dan menyediakan produk yang dapat lebih bernilai dan bermanfaat untuk memenuhi kebutuhan dan keinginan masyarakat.

Kreativitas dan inovasi merupakan unsur penting dalam kewirausahaan. Selama beberapa tahun terakhir ini, kewirausahaan telah menjadi salah satu topik yang dibahas dalam proses pembelajaran siswa di berbagai tingkat, baik di tingkat pendidikan dasar, menengah, hingga tingkat pendidikan tinggi. Kesadaran untuk mengembangkan kreativitas dan inovasi sejak usia muda sudah makin meningkat. Pada dasarnya setiap anak dilahirkan dengan membawa potensi kreatif. Oleh karena itu, anak perlu dibimbing dan diarahkan untuk mengembangkan potensi kreatifnya tersebut secara optimal.

Kegiatan kewirausaahan dapat dipahami sebagai implementasi dari faktor kreatif dan inovatif, yang didalamnya semua sumber daya diarahkan untuk mencapai tujuan tertentu. Pola pikir mengenai kewirausahaan tidak dapat dilepaskan dari kedua faktor tersebut karena melalui kedua faktor tersebut, pelaku kegiatan kewirausahaan dapat mengidentifikasikan dan menciptakan masalah dan menciptakan solusi terhadap masalah tersebut (berinovasi dan menciptakan sesuatu) (Barba-Sánchez \& Atienza-Sahuquillo, 2018). 
Dalam upaya mengembangkan kreativitas melalui program kewirausahaan, maka diperlukan aktivitas-aktivitas positif yang mengandung ide kreatif. Salah satu kegiatan positif yang diadakan oleh pihak mitra kegiatan pengabdian kepada masyarakat, dalam hal ini adalah SMP Al-Jannah Islamic, Nature, dan Science School yang berlokasi di Pondok Rangon, Jakarta Timur adalah program entrepreneur study. Kegiatan entrepreneur study merupakan kegiatan pengenalan program kewirausahaan kepada para siswa/i di sekolah tersebut. Tema kegiatan entrepreneur study yang dilaksanakan pada semester ini adalah pengenalan program kewirausahaan berbasis industri kreatif.

Sistem ekonomi berbasis industri kreatif diyakini oleh banyak pihak dapat menjadi solusi dalam mengatasi masalah pengangguran di Indonesia, sekaligus juga menjadi alternatif dalam menghadapi tantangan ekonomi global (Syariful, 2018). Dalam industri kreatif, setiap pelaku usaha harus memiliki pengetahuan dan informasi yang memadai untuk menciptakan berbagai ide yang kreatif, yang tidak hanya meniru usaha yang telah ada. Ide kreatif mereka tersebut diharapkan mampu menciptakan barang yang bernilai tinggi, dalam arti dapat bermanfaat demi pemenuhan kebutuhan dan keinginan orang lain yang menjadi pelanggannya.

Terkait dengan industri kreatif, generasi muda, terutama para siswa/i di berbagai tingkat pendidikan, menjadi ujung tombak untuk menghasilkan berbagai produk yang kreatif dengan mengandalkan pengetahuan dan informasi yang mereka dapatkan, baik di lingkungan keluarga maupun lingkungan sekolah. Dengan semakin meningkatnya kesadaran para siswa/i terhadap kegiatan kewirausahaan, maka akan semakin banyak wirausaha yang akan muncul di masa depan. Hal tersebut tentu juga akan berdampak pada meningkatnya perkembangan ekonomi nasional.

Menyikapi makin meningkatnya perhatian pemerintah akan pentingnya pendidikan Kewirausahaan di tiap tingkat pendidikan, Kepala SMP Al-Jannah menyampaikan permintaan pada Tim PKM Untar untuk dapat membantu program pengenalan kewirausahaan kepada para siswa/i di sekolah tersebut. Oleh karena itu, pihak SMP Al-Jannah juga memandang pentingnya pengenalan dunia usaha bagi para siswa, mengingat sejauh ini para siswa masih belum terlalu memahami esensi kegiatan kewirausahaan. Pihak sekolah memiliki kepedulian yang besar untuk mengembangkan jiwa kewirausahaan pada siswanya dan menumbuhkan keinginan berwirausaha di masa mendatang bagi para siswanya.

\section{Permasalahan Mitra}

Di tengah giatnya pemerintah mengembangkan program kewirausahaan dan untuk mendorong munculnya wirausaha-wirausaha baru, terutama wirausaha muda, maka Kepala SMP Al-Jannah memandang perlunya peran aktif dari para guru dan siswa dari sekolah ini dalam mendukung program kewirausahaan secara nasional.

Mengingat Kewirausahaan belum menjadi mata pelajaran wajib di sekolah, maka pihak sekolah merasa perlu adanya program pengenalan kewirausahaan. Oleh karena itu, pihak sekolah meminta bantuan pada tim PKM Untar untuk mengisi kegiatan entrepreneur study yang akan diadakan oleh pihak sekolah pada tanggal 30 Maret - 3 April 2020. Tim PKM Untar diminta untuk menjadi narasumber dalam kegiatan seminar dan workshop kewirausahaan. Namun demikian, karena sejak Maret 2020 sistem pembelajaran di sekolah diberlakukan online learning, maka kegiatan ini diundur ke tahun ajaran baru 2020.

Tujuan dari kegiatan ini secara umum adalah untuk mengenalkan kewirausahaan dan pentingnya memiliki karakteristik wirausaha sebagai sebuah karakter yang mampu mencetak pribadi-pribadi unggul di masa depan, yang diharapkan dapat membantu meningkatkan perekonomian negara di masa depan. 
Beberapa kegiatan sebelumnya yang pernah dilaksanakan di sekolah tersebut pada tahun 2018 adalah workshop pengembangan ide bisnis. Namun pada saat itu peserta hanya terbatas pada siswa kelas IX saja. Pada kegiatan kali ini, pihak sekolah ingin mengadakan kegiatan yang pesertanya adalah para siswa/i kelas VII, VIII, dan IX. Dengan demikian diharapkan kegiatan pengenalan kewirausahaan dapat disosialisasikan sejak dini dan diharapkan dapat berkelanjutan.

Adapun tujuan kegiatan ini adalah untuk memberikan pengetahuan mengenai pembuatan produk berbasis industri kreatif dan meningkatkan kesadaran siswa untuk melaksanakan kegiatan kewirausahaan.

\section{Solusi Mitra}

Solusi permasalahan yang dihadapi mitra adalah melalui pengadaan kegiatan seminar dan workshop berbasis industri kreatif dalam acara entrepreneur study yang diselenggarakan oleh pihak sekolah, dengan mengundang tim PKM Untar sebagai narasumber. Pada kegiatan seminar, para siswa akan dibekali pengetahuan mengenai konsep kewirausahaan, pengembangan ide bisnis dan juga melakukan simulasi bisnis. Pada kegiatan workshop, para siswa akan dibekali dengan keterampilan untuk membuat produk yang disesuaikan dengan minat dan kemampuan para siswa untuk membuatnya.

Menurut penelitian Adekiya dan Ibrahim (2016), pengadaan kegiatan pelatihan kewirausahaan berhubungan erat dengan peningkatan minat untuk melaksanakan kegiatan kewirausahaan dan perilaku untuk mengimplementasikan kegiatan kewirausahaan.

Pengadaan kursus atau kegiatan pelatihan keterampilan sebagai bagian dari program kewirausahaan juga akan meningkatkan keyakinan diri bagi pesertanya untuk mengimplementasikan kegiatan kewirausahaan (Mozahem \& Adlouni, 2021).

Kegiatan ekonomi dan industri kreatif terus digalakkan oleh pemerintah dengan melakukan program pendampingan ke pelaku ekonomi kreatif melalui inkubator bisnis yang terus dilakukan. Upaya pengembangan ekonomi kreatif tersebut tidak hanya menyasar kepada perseorangan dan komunitas, tapi juga wilayah melalui kota kreatif dan desa kreatif. Berbagai ruang kreatif juga difasilitasi untuk dibuka (Rusman, 2018).

Industri kreatif juga dapat dilakukan melalui pengembangan produk kuliner. Produk kuliner seringkali dipilih untuk dikembangkan karena dianggap lebih mudah dan kuliner merupakan kebutuhan orang banyak. Sektor kuliner mempunyai potensi yang sangat kuat untuk berkembang. Dibuktikan sektor ini memberikan kontribusi yang cukup besar, yaitu tiga puluh persen dari total pendapatan sektor pariwisata dan ekonomi kreatif. (jurnalmanajemen.com, 2019)

Oleh karena itu, pihak sekolah tertarik mengadakan workshop pembuatan produk kuliner berupa makanan ringan yang nantinya akan dibuat dengan berbagai rasa yang kekinian dan juga dikemas juga dengan disain kemasan yang menarik. Makanan ringan juga lebih mudah dibuat oleh para siswa/i serta biasanya juga disukai oleh berbagai kalangan dan harganya terjangkau.

Sejalan dengan program SMP Al-Jannah yang ingin menjadi sekolah yang kreatif dan ramah lingkungan, maka dalam kegiatan entrepreneur study tersebut, tim PKM akan mengundang narasumber yang menjadi pelaku usaha kecil dan menengah (UKM) industri kreatif yang memproduksi makanan berbahan baku lokal dan ramah lingkungan, yakni pemilik keripik singkong Cantir. 
Dalam kegiatan workshop, narasumber tersebut akan memberikan pelatihan singkat mengenai proses pembuatan keripik singkong sebagai contoh produk industri kreatif bidang kuliner.

\section{METODE PELAKSANAAN PKM}

Dalam merancang kegiatan PKM ini, Tim PKM Untar menjalankan beberapa metodologi, di antaranya adalah studi literatur mengenai berbagai bidang ilmu terkait dengan penyelenggaraan pembelajaran kewirausahaan di sekolah. Selain melakukan studi literatur, tim juga melakukan indepth interview dengan pihak-pihak penting, baik perwakilan dari pihak sekolah maupun beberapa ahli di bidang pendidikan kewirausahaan, guna mengetahui permasalahan utama yang dapat dibantu pencarian solusinya oleh Tim PKM Untar. Adapun tahap kegiatan yang dilakukan dapat dilihatt pada Gambar 1.

\section{Gambar 1}

\section{Tahap Kegiatan}

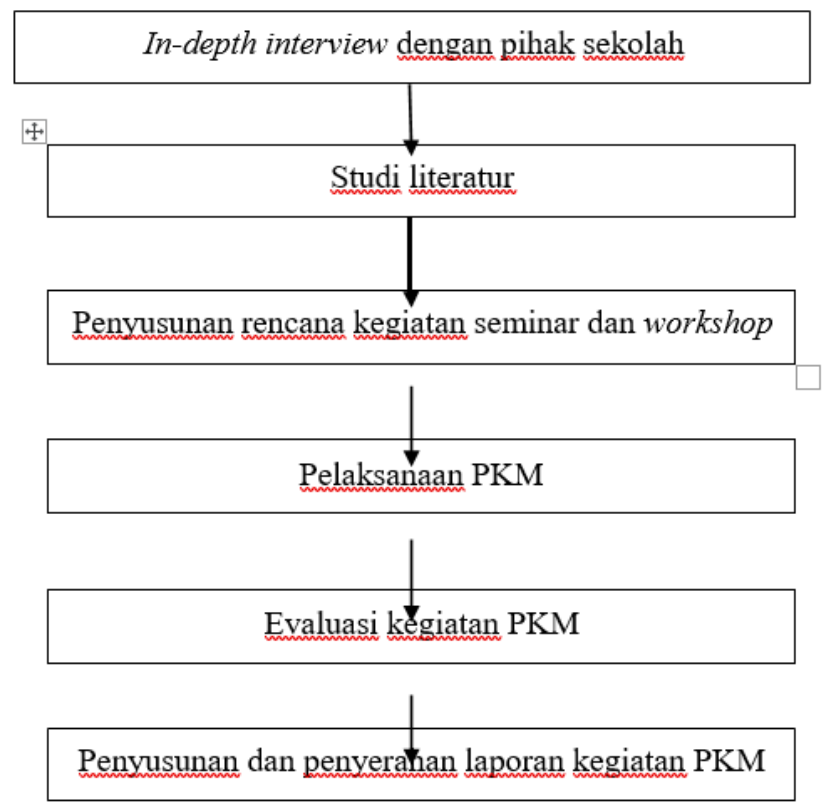

Tahap pertama pelaksanaan kegiatan adalah melakukan in deep interview, yang merupakan proses untuk memperoleh keterangan dengan cara melakukan tanya jawab secara tatap muka antara pewawancara (tim PKM) dengan responden atau orang yang diwawancarai (pihak sekolah, yang dalam hal ini adalah kepala sekolah dan guru BK (Bimbingan Karir).

Tahap kedua adalah melakukan studi literatur yang relevan dari berbagai sumber mengenai topik kewirausahaan, terutama yang terkait dengan industri atau ekonomi kreatif. Tahap ketiga adalah menyusun rencana kegiatan seminar dan workshop. Seminar ditujukan untuk mengenalkan konsep kewirausahaan kepada para siswa/i. Selain itu mereka juga diberi pengetahuan mengenai industri kreatif yang sedang menjadi program andalan pemerintah dalam meningkatkan perekonomian negara Indonesia. Pada tahap ini tim PKM menyusun materi dalam bentuk video yang akan ditayangkan ke para siswa Al Jannah.

Tahap keempat adalah pelaksanaan kegiatan PKM. Pelaksanaan kegiatan awalnya direncanakan antara tanggal 30 Maret - 3 April 2020, bertepatan dengan pelaksanaan acara entrepreneur study. Namun karena adanya perubahan system pembelajaran menjadi pembelajaran secara online (home based learning), maka kegiatan baru dapat dilaksanakan pada tanggal 20 Juli 2020. Kegiatan 
diubah menjadi Virtual Foodtech dengan menayangkan video tentang usaha kuliner kepada para siswa.

Tahap kelima adalah evaluasi kegiatan. Pada tahap ini, pelaksanaan kegiatan seminar dan workshop akan dievaluasi melalui survei dalam bentuk google form yang diisi oleh para peserta kegiatan. Tahap keenam adalah penyusunan dan penyerahan laporan kegiatan. Pada tahap ini, semua kegiatan dan dokumentasi disusun dalam bentuk laporan kegiatan.

\section{HASIL DAN PEMBAHASAN}

Pelaksanaan kegiatan tahap pertama adalah melakukan in deep interview. Hasilnya adalah gambaran keadaan Pendidikan kewirausahaan di SMP Al-Jannah dan permintaan pihak sekolah kepada Tim PKM untuk mengadakan program kewirausahaan.

Pelaksanaan kegiatan tahap kedua adalah studi literatur. Hasil dari penelusuran literatur digunakan untuk menyusun proposal kegiatan. Pelaksanaan kegiatan tahap ketiga adalah menyusun rencana kegiatan. Hasilnya adalah kegiatan akan dilaksanakan dalam bentuk seminar dan workshop.

Pelaksanaan kegiatan tahap keempat adalah pelaksanaan kegiatan PKM, yang diselenggarakan pada tanggal 20 Juli 2020. Mengingat kondisi pandemic Covid-19, maka kegiatan dilaksanakan secara daring dan menggunakan media video.

Pihak SMP Al Jannah menugaskan para siswa untuk menyaksikan video yang dishare melalui grup Whatsapp kelas 7, 8 dan 9. Video yang telah dibuat oleh tim PKM dishare sebagai bagian dari kegiatan pembelajaran siswa dan program Virtual Foodtech yang merupakan program rutin sekolah setiap semesternya. Program Foodtech biasanya diselenggarakan dalam bentuk workshop di sekolah. Namun karena situasi pandemi Covid-19 mengharuskan sekolah diselenggarakan secara offline, maka kali ini bentuk kegiatannya disarikan dalam video yang dipelajari oleh siswa dan kemudian siswa mempraktikkan sendiri di rumah.

\section{Gambar 2}

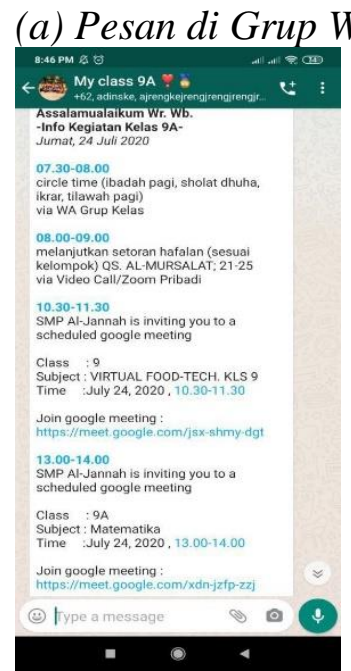

(a)

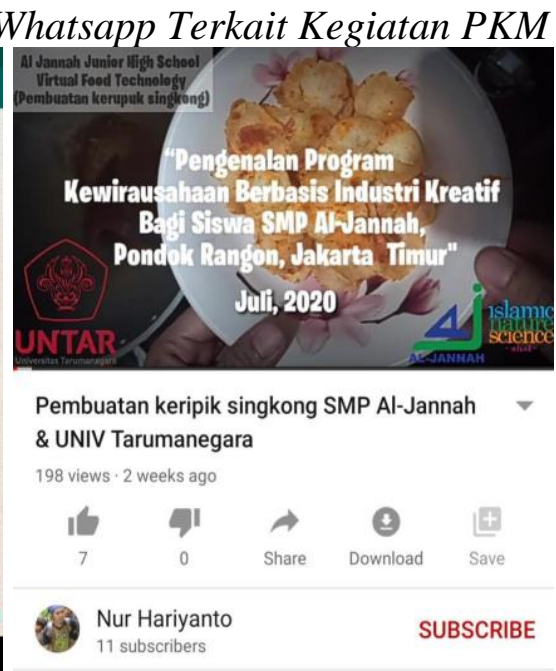

(b)

Gambar 2 (a) menampilkan pesan wali kelas kepada siswa terkait pembelajaran harian dan program Virtual Foodtech. Video Virtual Foodtech ini juga diupload di Youtube sebagai dokumentasi dan untuk memperluas sebaran pemirsa seperti dapat dilihat di Gambar 2 (b). 
Pelaksanaan kegiatan tahap kelima adalah evaluasi kegiatan, yang dilakukan melalui penyebaran google form kepada para siswa/i. Evaluasi atas kegiatan PKM secara rinci dapat dilihat dari respon siswa dalam kuesioner yang disebarkan. Respon terbagi atas profil siswa, evaluasi materi PKM, dan saran umum. Berikut ini adalah penjelasan mengenai hasil evaluasi oleh siswa.

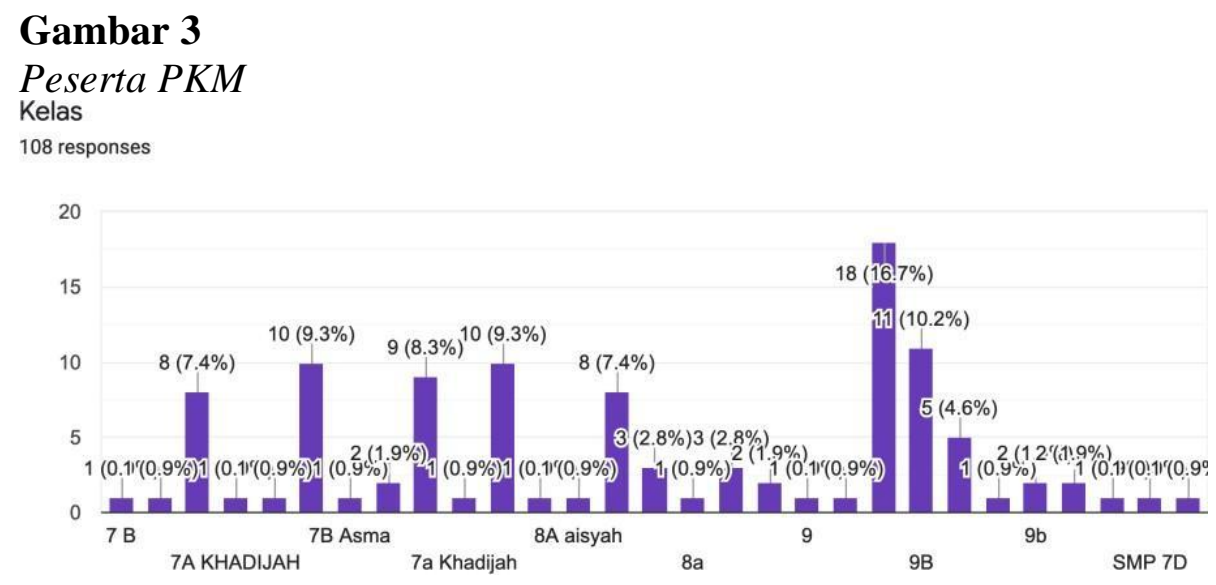

\section{Profil Siswa}

Pada Gambar 3 dapat dilihat peserta PKM sebanyak 108 siswa yang terdiri dari siswa kelas 7, 8 dan 9. Sebagaimana ditampilkan pada Gambar 4, sebanyak 49,1\% orang tua siswa memiliki bisnis dan $50,9 \%$ orang tua siswa tidak memiliki bisnis. Bisnis yang dimiliki oleh orang tua siswa sangat bervariasi, mulai dari kontraktor bangunan, perkebunan, online shop, jasa penerjemah, konveksi, bisnis kuliner, konsultan, peternakan, laundry, bengkel, hingga pertamanan.

\section{Gambar 4}

Bisnis yang Dimiliki Orang Tua

Apakah orang tua ananda memiliki bisnis?

108 responses

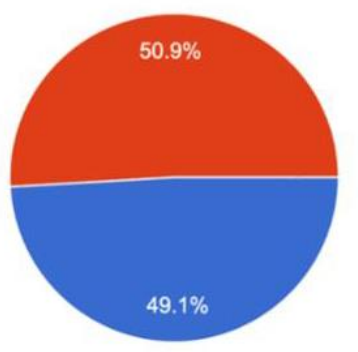

\section{Evaluasi Materi PKM}

Terkait dengan materi yang disampaikan dalam video PKM, siswa memberikan evaluasi dalam hal kejelasan materi, manfaat yang diperoleh, keterampilan yang didapatkan, serta minat kewirausahaan. Pada pernyataan mengenai "Video yang ditampilkan menarik", terdapat sebanyak 28 siswa menyatakan Sangat Setuju, 43 siswa Setuju dan 36 siswa Netral dan 1 siswa Kurang Setuju. Hal ini menunjukkan bahwa mayoritas siswa mengevaluasi video PKM menarik bagi mereka. Tabulasi jawaban siswa dapat dilihat pada Gambar 5 (a). 


\section{Gambar 5}

(a) Kemenarikan Materi PKM (b) Kejelasan Materi PKM

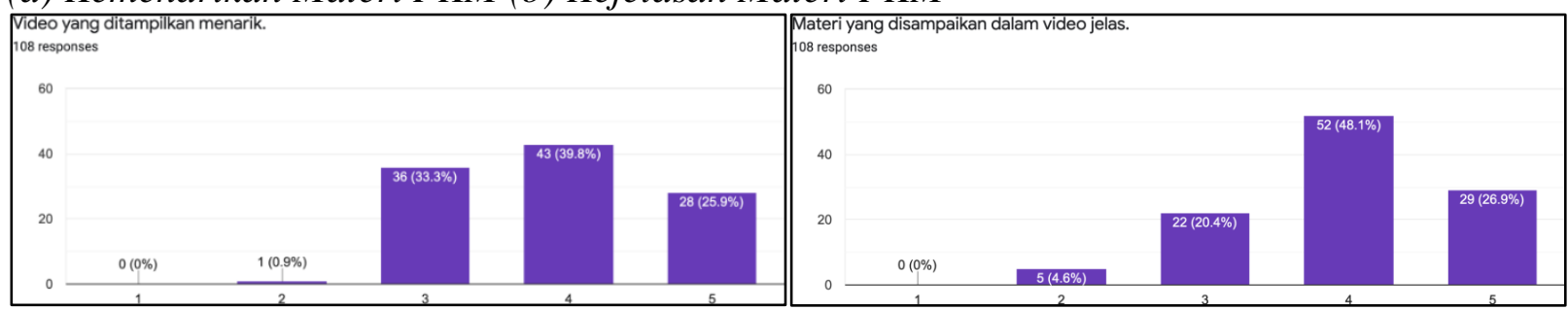

(a)

(b)

Gambar 5 (b) menampilkan respon siswa atas kejelasan materi PKM. Sebanyak 29 siswa menyatakan Sangat Setuju bahwa Materi yang disampaikan dalam video jelas, 52 siswa menyatakan Setuju, 22 siswa menyatakan Netral dan 5 siswa menyatakan Tidak Setuju. Dengan demikian dapat disimpulkan pula bahwa mayoritas siswa menyatakan bahwa mereka setuju materi yang disampaikan dalam video jelas.

Manfaat yang diperoleh setelah menyaksikan video diukur dengan pernyataan Materi yang disampaikan dalam video bermanfaat. Terdapat 58 siswa menyatakan Sangat Setuju, 39 siswa menyatakan Setuju dan 11 siswa menyatakan Netral mengenai manfaat video. Tabulasi respon siswa dapat dilihat pada Gambar 6. Mayoritas siswa menyatakan bahwa materi yang disampaikan dalam video bermanfaat.

\section{Gambar 6}

\section{Manfaat Kegiatan PKM}

Materi yang disampaikan dalam video bermanfaat. 108 responses

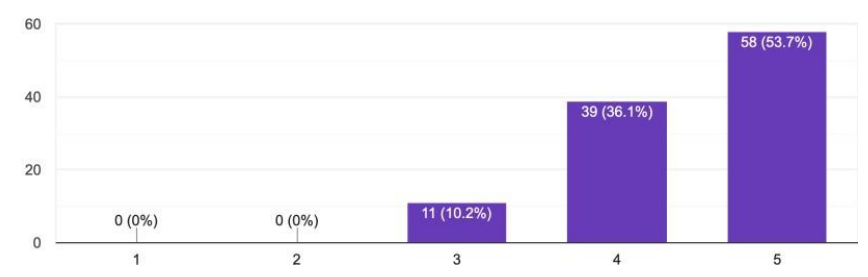

Siswa juga diminta untuk menilai sejauh mana kemampuan mereka mengikuti instruksi yang disampaikan dalam video. Mereka diminta memberikan penilaian pada pernyataan Saya dapat mengikuti instruksi dalam video dengan baik. Sebanyak 19 siswa menyatakan Sangat Setuju, 56 siswa Setuju, 28 siswa Netral dan 5 siswa Tidak Setuju. Hal ini menunjukkan bahwa mayoritas siwa menyatakan mereka dapat mengikuti instruksi dalam video dengan baik. Gambar 7 menampilkan tabulasi respon siswa terkait hal ini.

\section{Gambar 7}

Kemudahan Instruksi dalam Video

Saya dapat mengikuti instruksi dalam video dengan baik.

108 responses

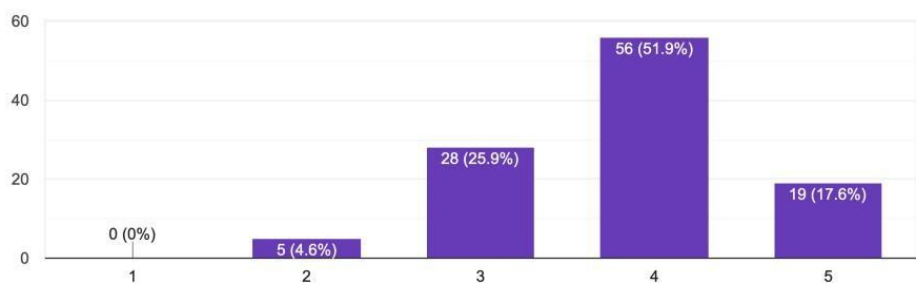


Siswa juga diminta untuk memberikan pernyataan terkait pemahaman tentang usaha kuliner dan minat berwirausaha di masa mendatang setelah melihat tayangan dalam video. Gambar 8 menampilkan respon siswa mengenai pemahaman atas usaha bidang kuliner. Sebanyak 32 siswa menyatakan Sangat Setuju, 42 siswa Setuju, 31 siswa Netral dan 3 siswa Tidak Setuju bahwa setelah melihat tayangan video PKM mereka dapat memiliki pemahaman mengenai jenis usaha kuliner. Mayoritas siswa menyatakan bahwa mereka memiliki pemahaman mengenai jenis usaha kuliner setelah menyaksikan video.

\section{Gambar 8}

\section{Pemahaman Setelah Mengikuti Kegiatan PKM}

Setelah melihat tayangan video ini saya dapat memiliki pemahaman tentang jenis usaha kuliner. 108 responses

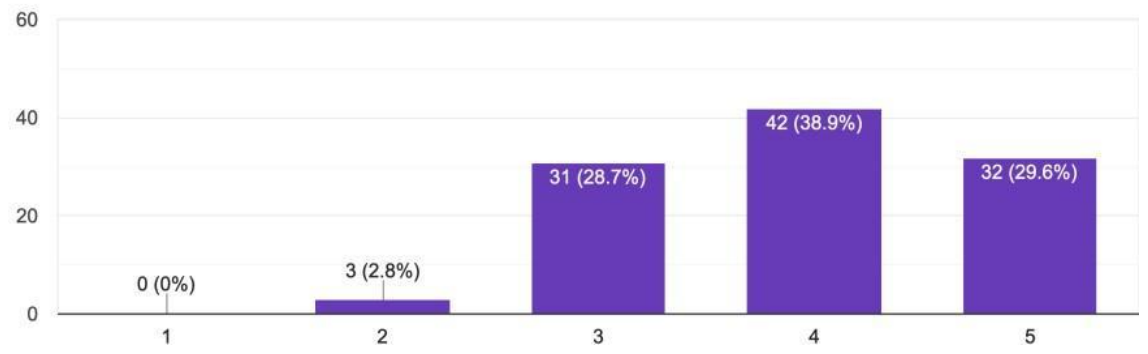

Terkait dengan minat berwirausaha, siswa diminta memberikan pernyataan mengenai minat membuka usaha di bidang kuliner di masa mendatang. Terdapat sebanyak 15 siswa Sangat Setuju, 23 siswa Setuju, 47 siswa Netral, 19 siswa Tidak Setuju, dan 4 siswa Sangat Tidak Setuju. Melalui Gambar 9 dapat dilihat tabulasi respon siswa mengenai hal ini. Tidak dapat dipungkiri bahwa kita tidak mungkin memaksa setiap orang untuk berwirausaha. Namun demikian, dari hasil jawaban siswa dapat dilihat bahwa 35,2\% siswa menyatakan tertarik untuk menjalankan usaha kuliner di masa mendatang setelah melihat tayangan video.

\section{Gambar 9}

Minat Berwirausaha Siswa

Setelah melihat tayangan video ini saya tertarik untuk menjalankan usaha kuliner di masa mendatang.

108 responses

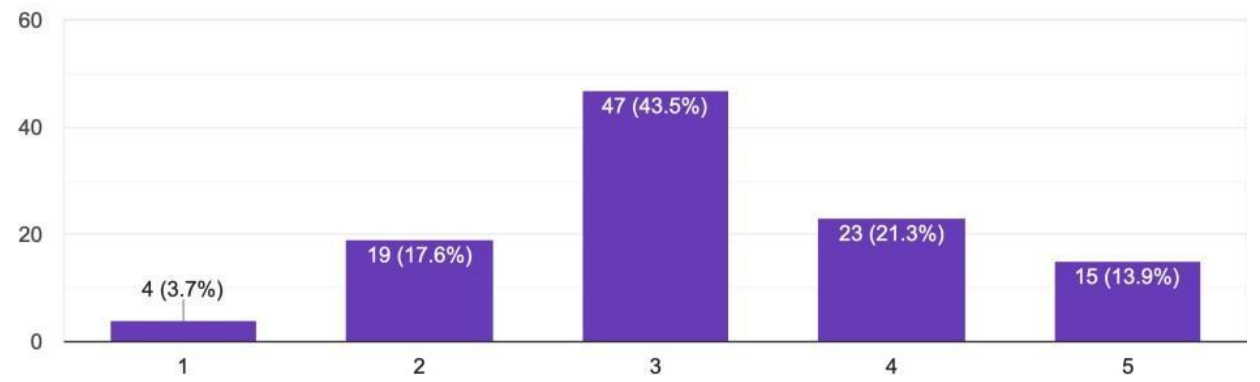

\section{Saran Umum}

Pada bagian akhir evaluasi, siswa juga diminta untuk memberikan saran secara umum terkait kegiatan PKM dan materi apa yang mereka harapkan di masa mendatang. Siswa menyampaikan bahwa secara umum materi yang disampaikan cukup baik dan bermanfaat, cara penyajian materi baik dan mudah dipahami. Adapun materi yang disarankan untuk kegiatan berikutnya diantaranya adalah mengenai cara memulai usaha, materi mengenai kreativitas, cara menjadi pengusaha 
sukses, cara membuat iklan yang menarik, teknik pemasaran, serta strategi mendapatkan pelanggan.

\section{KESIMPULAN DAN SARAN}

Melalui kegiatan pengabdian kepada masyarakat ini, para siswa/i menjadi lebih memahami mengenai kewirausahaan, terutama mengenai produk yang termasuk dalam industri kreatif. Pengetahuan pembuatan produk berbasis industri kreatif ini akan diimplementasikan dalam kegiatan entrepreneur study yang diadakan pihak sekolah.

Secara umum kegiatan ini berjalan sesuai dengan baik, walau terdapat kendala dalam pelaksanaannya. Seluruh peserta memberikan tanggapan positif yang diperoleh melalui pengisian google form.

Di masa mendatang kegiatan PKM dengan metode ini dapat dilakukan pada mitra yang sama atau berbeda. Topik kegiatan PKM dapat diperluas sesuai dengan latar belakang keilmuan tim PKM serta kebutuhan mitra.

\section{REFERENSI}

Adekiya, A., \& Ibrahim, F. (2016). Entrepreneurship intention among students. The antecedent role of culture and entrepreneurship training and development. The International Journal of Management Education, 14. 116-132. http://dx.doi.org/10.1016/j.ijme.2016.03.001

Barba-Sánchez, V., \& Atienza-Sahuquillo, C. (2018). Entrepreneurial intention among engineering students: The role of entrepreneurship education. European Research on Management and Business Economics, 24, 53-61. http://dx.doi.org/10.1016/j.iedeen.2017.04.001

Destiani, A., Saparahayuningsih, S., \& Wembrayarli. (2016). Upaya peningkatan kreativitas seni rupa siswa melalui teknik pencetakan dengan bantuan media asli. Jurnal Ilmiah Potensia, 1(1). 7-14.

Hasanah, L. L. N. E. (2015). Pengembangan wirausaha muda ekonomi kreatif berbasis budaya di Daerah Istimewa Yogyakarta. Jurnal Studi Pemuda, 4(2), 268-280.

Jayalakshmi, P. \& Saranya, A. S. (2015). Entrepreneurial intention among students of arts and science colleges in chennai: an empirical study. International Journal on Information Sciences and Computing, 9(1), 6-15.

Jurnalmanajemen.com (2019, Agustus 10). 16 Contoh industri kreatif di Indonesia paling diminati. 10 Agustus 2019. https://jurnalmanajemen.com/industri-kreatif/

Lynch, M., Kamovich, U., Longva, K. K., Steinert, M. (2021). Combining technology and entrepreneurial education through design thinking: Students' reflections on the learning process. Technological Forecasting \& Social Change, 164. 1-11. https://doi.org/10.1016/j.techfore.2019.06.015

Mozahem, N. A., \& Adlouni, R. O. (2021). Using entrepreneurial self-efficacy as an indirect measure of entrepreneurial education. The International Journal of Management Education, 19, 1-10. https://doi.org/10.1016/j.ijme.2020.100385.

Rusman, M. (2018, Mei 3). Dongkrak industri kreatif capai Rp1.000T. bisnissulawesi.com

http://bisnissulawesi.com/2018/03/05/dikebut-tiga-bendungan-di-sulsel/

Syariful. (2018). Ekonomi kreatif berbasis kearifan lokal di Bangka Belitung. ACTIVA: Jurnal Ekonomi Syariah, 1(2), 1-17. 